\title{
ISOLATION AND IDENTIFICATION OF BACTERICIDE AND MITICIDE COMPOUND FROM SCHINUS TEREBINTHIFOLIUS LEAVES AGAINST THE POTATO ROT BACTERIA AND SPIDER MITE
}

\author{
Abdalla M. Moussa ${ }^{1}$; Ahmed M. Emam ${ }^{1}$; Mamdouh A. Mohamed ${ }^{1}$ and Ashraf \\ A. Rahil ${ }^{2}$ \\ 1-Biochemistry Department, Faculty of Agriculture, Cairo University, Fayoum Branch, Egypt. \\ 2- Plant Protection Department, Faculty of Agriculture, Cairo University, Fayoum Branch, \\ Egypt.
}

\begin{abstract}
The $\mathrm{MeOH}$ extracts of 26 plant species belonging to 18 plant families were examined against the two spotted spider mite Tetranychus urticae and the two pathogenic, brown rot bacterium Ralstonia solanacearum and soft rot bacterium Erwinia carotovora. The results indicated that Schinus terebinthifolius was the most potent plant for controlling these pests as its methanol extract exerted highly activity against the two pathogenic bacteria in addition to moderate activity against the spider mite. The $\mathrm{MeOH}$ extract of this plant was purified by using a combination of different chromatographic methods (column chromatography and TLC) to yield an active pure compound. Based on spectroscopic methods $\left({ }^{1} \mathrm{H},{ }^{13} \mathrm{C}-\mathrm{NMR}, \mathrm{UV}\right.$ and MS) the isolated compound was characterized as gallic acid methyl ester, which exerted a miticidal activity against the two spotted spider mite Tetranychus urticae $\left(\mathrm{LC}_{50}=58 \mathrm{mg}^{-1}\right)$ and antibacterial activity against Erwinia carotovora and Ralstonia solanacearum_ (MLC $=250$ and $500 \mu \mathrm{g} / \mathrm{ml}$ ), respectively.
\end{abstract}

Key words: Bactericide, Miticide, Schinus terebinthifolius, Potato Rot Bacteria, Spider mite and Methyl gallate

\section{INTRODUCTION}

Potato is one of the most important vegetable crops in Egypt. Its importance is not only due to local consumption but also for potato exportation to European community which represents about $42.7 \%$ of Egypt's agricultural exports (Food and Veterinary Office 2000).

There are two specific problems that limit potato production and exportation. Firstly; leaf infestation by the two spotted spider mite, (Tetranychus urticae). Secondly; tubers infections in the field by the bacterium, Ralstonia solanacearum (brown rot disease) or during the storage by the bacterium Erwinia carotovora (soft rot disease) Barakat et al. (1984), Elphinstone (2001) and Toth et al. (2003).

In the few recent years, Egypt has lost several million dollars as a result of turning back the Egyptian potatoes imported by the European community due to infections with brown rot disease (Food and Veterinary Office 2000).

Synthetic pesticides such as Chalenger (160ml/ Feddan), Rovral (500ml/feddan) and Tecto $5 \% \mathrm{D}(1.25 \mathrm{Kg} /$ Ton tuber) have been used for control the mite, brown rot and soft rot diseases, respectively. While these pesticides have done much to improve yields of high quantity of potatoes, the

Fayoum J. Agric. Res. \& Dev., Vol.19, No.2, July, 2005 
long term use of synthetic pesticides has harmful effects on human beings, beneficial organisms and environment. The replacement of synthetic by natural pesticides for pest control applications has increased interest in the potential use of natural products in general.

Therefore the present study was undertaken to survey some local plants for both miticidal activity against the two spotted spider mite Tetranychus urticae and antibacterial activity against brown rot bacterium Ralstonia solanacearum and soft rot bacterium Erwinia carotovora, along with the isolation and identification of active constituent(s) from the most active plant(s).

\section{MATERIAL AND METHODS}

\section{1- Plant material}

Leaf samples of 26 plant species belonging to 18 plant families (Table1) were collected from Fayoum Faculty of Agriculture garden and were identified by the Botany Department, Faculty of Science, Cairo University. A voucher specimen of each plant was deposited in the herbarium of the Department of Biochemistry, Faculty of Agriculture, Fayoum Branch, Cairo University.

A portion $(100 \mathrm{~g})$ of the leaf samples of each plant species collected was air dried in the shade, ground into a fine powder and then were extracted with methanol. The methanol extracts of the leaf samples were evaporated to dryness and screened for both; miticidal activity against the two spotted spider mite Tetranychus urticae, and antibacterial activity against the brown rot bacterium; Ralstonia solanacearum and soft rot bacterium; Erwinia carotovora.

\section{2- Biological evaluation:}

\subsection{Miticidal activity}

The miticidal activity of the methanol extracts of plant species was tested according to the slide-dip technique adopted by Voss (1961) and modified by Dittrich (1962) against adult females of Tetranychus urticae isolated locally in Department of Plant Protection, Faculty of Agriculture, Fayoum Branch. For this purpose, a piece of double face adhesive scotch tape was pressed tightly to the surface of a microscopic glass slide. Five aqueous concentrations $\left(50,100,200,400\right.$ and $\left.800 \mathrm{mg}^{-1}\right)$ of each plant extract were used to draw the dosage mortality regression line. Ten adult females were adhered upside down with legs free to the tape on the glass slide and immediately dipped in the aqueous extracts for about 5 seconds. Four replicate slides were used for each aqueous concentration. The mortality ratios were recorded after $24 \mathrm{~h}$. The $\mathrm{LC}_{50}$ values were determined by computerized probit analysis program.

\subsection{Antibacterial activity}

2.2.1 Tester strains : Ralstonia solanacearum and Erwinia carotovora were obtained from Department of Plant Pathology, Faculty of Agriculture Ain shams University.

\subsubsection{Preliminary test:}

The antibacterial activity of the methanol extract was determined in vitro by the filter paper disc agar diffusion method according to Bauer et al., (1966) as follows

Fayoum J. Agric. Res. \& Dev., Vol.19, No.2, July, 2005 
ISOLATION AND IDENTIFICATION OF BACTERICIDE AND..... 58

The sterile whatmann No.1 filterpaper discs $(6 \mathrm{~mm})$ were soaked with each methanolic plant extract $(1 \mathrm{~g} / 10 \mathrm{ml} \mathrm{MeOH})$ and dried at $40^{\circ} \mathrm{C}$, the sterile discs were placed over the seeded LPN agar plates (LPN agar contained about to colony forming units $/ \mathrm{ml}$ ). The plates were then incubated overnight at $37 \mathrm{C}^{\circ}$. All the determinations were carried out in triplicate and average zones of inhibition have been recorded in Table (1).

\subsubsection{Determination of Minimum Lethal Concentration (MLC)}

The MLC of the methanolic extract of the most potent plant and the active constituent (s) were determined by bacterial broth dilution method described by Ellen et al. 1994

The results of preliminary screening (Table 1) revealed that Schinus terebinthifolius was the most potent plant against both the spider mite and the two pathogenic bacteria, therefore, this plant was subjected to isolation and identification of the active constituent(s) responsible for these activities.

Table 1: List of plant species used in screening of miticidal and bactericidal activities.

\begin{tabular}{|l|c|c|c|c|}
\hline \multicolumn{1}{|c|}{ Plants scientific name } & Family name & \multicolumn{2}{|c|}{$\begin{array}{c}\text { Antibacterial activity } \\
\text { Inhibition zone of plant } \\
\text { extracts (mm) }\end{array}$} & $\begin{array}{c}\text { Miticidal } \\
\text { activity LC }_{\mathbf{5 0}} \\
\text { mg1 }^{\mathbf{1}}\end{array}$ \\
\cline { 3 - 4 } & & $\begin{array}{c}\text { Erwinia } \\
\text { carotravora }\end{array}$ & $\begin{array}{c}\text { Ralstonia } \\
\text { solanacearum } \\
\text { srticae }\end{array}$ \\
\hline Acacia farnesianal & Mimosaceae & 00 & 00 & 00 \\
\hline Lantana camara & Verbenaceae & 12 & 12 & 225 \\
\hline Vitex sp. & Verbenaceae & 00 & 00 & 00 \\
\hline Clerodendron inerme & Verbenaceae & 00 & 00 & 00 \\
\hline Bignonia sp. & Bignoniaceae & 00 & 00 & 00 \\
\hline Callistemon chinensis & Myrtaceae & 12 & 11 & 00 \\
\hline Myrtus communis & Myrtaceae & 25 & 26 & 190 \\
\hline Cassia sp. & Fabaceae & 11 & 11 & 140 \\
\hline Sesbania aegyptiaca & Fabaceae & 00 & 00 & 00 \\
\hline Parkinsonia sp. & Fabaceae & 00 & 00 & 00 \\
\hline Acacia saligna & Fabaceae & 00 & 00 & 250 \\
\hline Phyllanthus nivosus & Euphorbiaceae & 15 & 14 & 00 \\
\hline Hibiscus sp. & Malvaceae & 00 & 00 & 00 \\
\hline Neriam oleander & Apocynaceae & 00 & 00 & 00 \\
\hline Thevetia nereifolia & Apocynaceae & 00 & 00 & 00 \\
\hline Bouganvillea glabra & Nyctaginaceae & 18 & 20 & 00 \\
\hline Schinus terebinthifolius & Anacardiaceae & 30 & 28 & 230 \\
\hline Ficus nitida & Moraceae & 00 & 00 & 00 \\
\hline Ficus benjamina & Moraceae & 12 & 11 & 00 \\
\hline Zebrina pendula & Commelinaceae & 00 & 00 & 00 \\
\hline Binus sp. & Pinaceae & 00 & 00 & 00 \\
\hline Jasminum grandiflorum & Oleaceae & 00 & 00 & 00 \\
\hline Syngonium podophyllum & Araceae & 00 & 00 & 00 \\
\hline Melia azadirach & Meliaceae & 11 & 12 & 00 \\
\hline Nephrolepis exaltata & Oleandraceae & 00 & 00 & 00 \\
\hline Pittosporum tobira & Pittosporaceae & 00 & 11 & 150 \\
\hline & & & & \\
\hline
\end{tabular}

Fayoum J. Agric. Res. \& Dev., Vol.19, No.2, July, 2005 


\section{3- Extraction and Isolation of the bioactive constituent (s)}

\subsection{Extraction}

Ground air dried leaves (335g) of Schinus terebinthifolius was successively extracted with a series of solvents of increasing polarity: n-Hexan (3L), Chloroform (5L), Ethylacetat (3L) and Methanol (5L) at room temperature $\left(25^{\circ} \mathrm{C}\right)$.

The extracts were evaporated to dryness under reduced pressure to offer the following residues, Hexane $(10 \mathrm{~g}), \mathrm{CHCl}_{3}(20 \mathrm{~g})$ EtOAc $(2 \mathrm{~g})$ and $\mathrm{MeOH}$ $(55.6 \mathrm{~g})$, then the extracts were tested against both the spider mite and the two pathogenic bacteria.

\subsection{Analytical Thin Layer Chromatography (TLC)}

Analytical TLC was carried out on precoated silica gel plate $\left(\mathrm{F}_{245} 0.25 \mathrm{~mm}\right.$ and $\mathrm{F}_{225} 2.00 \mathrm{~mm}$ Merck ) using the following solvent systems:

1) n-Butanol- Acetic acid- Water (4:1:5) upper layer .

2) Ethylacetate- Acetic acid- Formic acid- Water (100:11:11:27) .

3) Chloroform- Methanol- Water (80:20:2)

4) Chloroform- Methanol (75:25)

Spots on TLC were detected under UV light $(254$ and $365 \mathrm{~nm})$ and by spraying with concentrated $\mathrm{H}_{2} \mathrm{SO}_{4}$ followed by heating at $105 \mathrm{C}^{\circ}$ for $5 \mathrm{~min}$. or by $\mathrm{FeCl}_{3} 5 \%$.

\subsection{Isolation of the bioactive component(s)}

The bioactive methanol extract was subjected to the isolation of the bioactive component(s)as fallows:

Thirteen grams of the methanol extract were subjected to column chromatography (CC) over silica gel (230-400 mesh, 500g) and elution with a gradient of $\mathrm{CHCl}_{3}: \mathrm{MeOH}: \mathrm{H}_{2} \mathrm{O}(70: 30: 5 ; 2.5 \mathrm{~L}, 60: 40: 5,30: 70: 0$ and $0: 100$ $: 01.5 \mathrm{~L}$ for each eluent). According to differences in composition monitored by TLC, 13 fractions were obtained and then tested for miticidal and antibacterial activities. The bioactive fraction (No: 3 eluted with 70:30:5 between $400-600 \mathrm{ml} 1.5 \mathrm{~g}$ ) was further separated by using $\mathrm{CC}$ on silica gel $(50 \mathrm{~g})$ with mixtures of $\mathrm{CHCl}_{3}: \mathrm{MeOH}$ as eluents (100:0, 95:5, 90:10 and 80:20; $200 \mathrm{ml}$ of each eluent). The eluents were combined on the basis of similar TLC profiles to afford 9 fractions (A-I). The most abundant fraction (No. E= $330 \mathrm{mg}$ eluted with 95:5 between 35:140 ml) which containing the major compound was further purified on Sephadex LH20 column $(20 \mathrm{~g})$ with $\mathrm{MeOH}$ as an eluent followed by preparative TLC with Ethylacetate: Formic acid: Acetic acid: Water $(100: 11: 11: 27)$ to give $230 \mathrm{mg}$ of pure compound. The purity of this active compound was established by its resolution as a single spot in four different TLC systems.

\subsection{Structure identification of the isolated compound}

The isolated compound was characterized by detection test and spectroscopic methods.

\subsubsection{Detection tests}

The preliminary screening of the isolated compound for the following classes of phytoconstituents saponins, flavonoids, alkaloids, glycosides and phenolic compounds was performed according to the methods described by Farnsworth (1966).

Fayoum J. Agric. Res. \& Dev., Vol.19, No.2, July, 2005 
ISOLATION AND IDENTIFICATION OF BACTERICIDE AND..... 60

3.4.2 Spectroscopic methods

\subsubsection{Nuclear Magnetic Resonance (NMR) Spectroscopy}

${ }^{1} \mathrm{H}$ and ${ }^{13} \mathrm{C}-\mathrm{NMR}$ Spectra were recorded in DMSO- $\mathrm{d}_{6}$ on a varion Mercury VXR $300\left(300 \mathrm{MHz}\right.$ for ${ }^{1} \mathrm{H}$ and $75 \mathrm{MHz}$ for $\left.{ }^{13} \mathrm{C}\right)$ chemical shifts were related to that of the solvent .

\subsubsection{Mass spectrometry (MS)}

Mass spectrum was recorded on a GCMS. QP 1000 Ex Shimadzu mass spectrometer at 70 e.v.

\subsubsection{UV spectrometry}

UV spectrum was recorded on Cecil 3000 series spectrophotometer according to Mabry et al. (1970).

\section{RESULTS AND DISCUSSION}

Table (1) showed that the miticidal activity $\left(\mathrm{LC}_{50}\right)$ and the antibacterial activity (average inhibition zones) of the methanolic extracts of the plants examined against the spider mite, Tetranychus urticae and the two pathogenic bacteria, Erwinia carotovora and Ralstonia solanacearum.

The results indicated that 11 methanolic extracts only exhibited biological activity against one or more of the three pests tested. The $\mathrm{LC}_{50}$ values of these extracts against the mite were between $140 \mathrm{mg}^{-1}$ for Cassia $\mathrm{sp}$ extract to 250 $\mathrm{mg}^{-1}$ for Acacia saligna extract, whereas the antibacterial activities (inhibition zones) were between $11 \mathrm{~mm}$ for Cassia $s p$. extract to $30 \mathrm{~mm}$ for Schinus terebinthifolius extract against Erwinia carotovora and between 11 $\mathrm{mm}$ for Cassia sp. extract to $28 \mathrm{~mm}$ for Schinus terebinthifolius extract against Ralstonia solanacearum. The results also revealed that only four extracts were found to have both miticidal and antibacterial activities against the three pests tested, these include the extracts of Lantana camera, Myrtus communis, Cassia sp. and Schinus terebinthifolius .

The Schinus terebinthifolius was the most potent plant for controlling the three tested pests as its methanol extract exerted highly activity against the two pathogenic bacteria in addition to moderate activity against the spider mite.

The air dried leaves of Schinus terebinthifolius were successively extracted by $\mathrm{C}_{6} \mathrm{H}_{14}, \mathrm{CHCl}_{3}$, EtOAc and $\mathrm{MeOH}$, then the miticidal and antibacterial activities of each extract were tested. Only the methanol extract showed miticidal activity $\left(\mathrm{LC}_{50}=200 \mathrm{mg}^{-1}\right)$ and antibacterial activity against the two pathogenic bacteria, Erwina carotovara and Ralstonia solanacearum $(\mathrm{MLC}=500$ and $1000 \mu \mathrm{g} / \mathrm{ml})$, respectively.

Analytical TLC of the active methanol extract $\left(\mathrm{CHCl}_{3}: \mathrm{MeOH}: \mathrm{H}_{2} \mathrm{O}\right.$; 80:20:2) showed the presence of a pink major component after spraying with $\mathrm{H}_{2} \mathrm{SO}_{4}$. This component was obtained as white powder $\left(230 \mathrm{mg} ; 1.77 \% \mathrm{R}_{\mathrm{f}}\right.$ $=0.91$ and 0.61 systems 1 and 3 , respectively) after purification through column chromatography and preparative TLC as described in Material and Methods.

The UV spectrum of the pure compound exhibited a distincit maximum at $\lambda=283 \mathrm{~nm}$. Also this compound gave positive reaction with $\mathrm{FeCl}_{3}$ (blue) on TLC indicating that it is a phenolic compound.

The mass spectrum of this compound (Fig.1) showed a molecular ion peak at $\mathrm{m} / \mathrm{z} 184$ which indicated that its molecular formula is $\mathrm{C}_{8} \mathrm{H}_{8} \mathrm{O}_{5}$. The presence of phenyl group was established by the appearance of carbon atom signals

Fayoum J. Agric. Res. \& Dev., Vol.19, No.2, July, 2005 
Abdalla M. Moussa, et al.

between $\delta 109.33$ to $\delta 146.51 \mathrm{ppm}$ in the ${ }^{13} \mathrm{C}-\mathrm{NMR}$ spectral data (Fig. 2 and Table 2). The ${ }^{13} \mathrm{C}-\mathrm{NMR}$ spectrum also showed the presence of methoxyl group $\left(\mathrm{OCH}_{3}\right)$ and carbonyl group $(\mathrm{CO})$ due to the carbon atom signals at $\delta 52.15$ and $\delta 167.09 \mathrm{ppm}$ respectively.

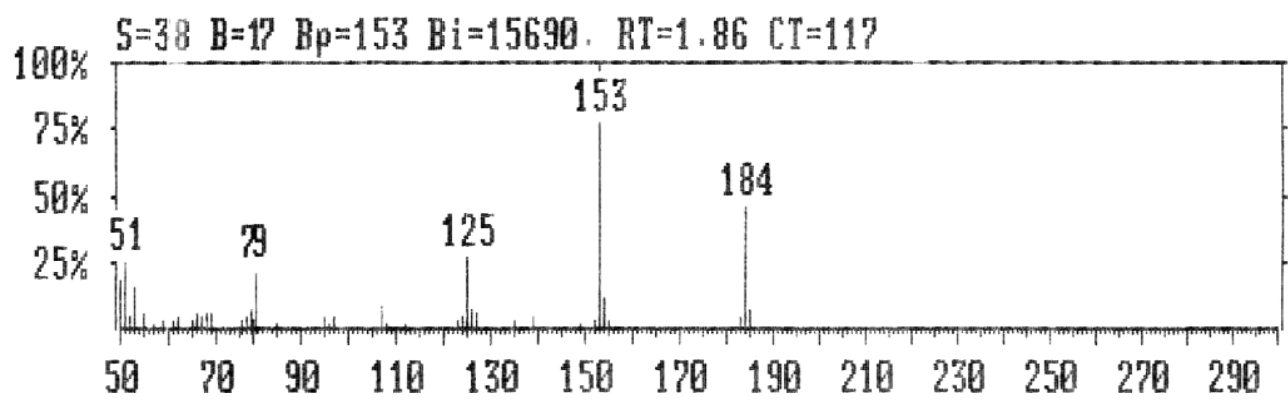

Fig. (1) The mass spectrum of the isolated compound
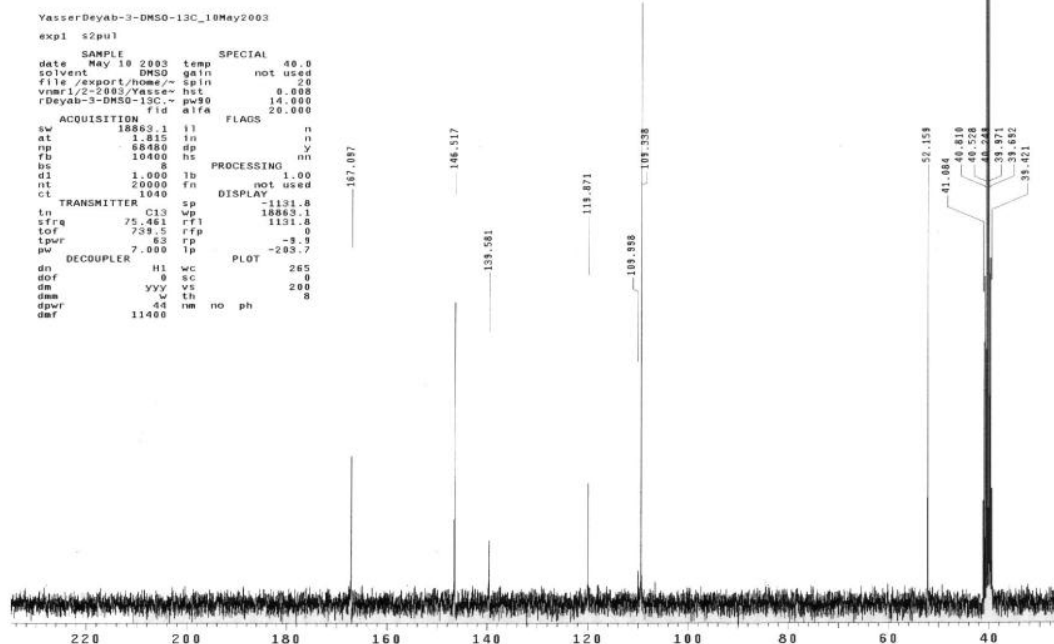

Fig. (2) ${ }^{13} \mathrm{C}$-NMR spectrum of the isolated compound in DMSO-d 6

Table (2) ${ }^{13} \mathrm{C}$ and ${ }^{1} \mathrm{H}$-NMR spectral data of the isolated compound in DMSO-d ${ }_{6}$

\begin{tabular}{|c|c|c|c|}
\hline Carbon No. & $\delta \mathrm{C}$ & ${ }^{\mathrm{I}} \mathrm{C}$ & ${ }^{\mathrm{I}} \mathrm{H}$ \\
\hline 1 & $\mathrm{C}$ & 119.87 & - \\
\hline 2 & $\mathrm{CH}$ & 109.33 & $6.93 \mathrm{~s}$ \\
\hline 3 & $\mathrm{C}$ & 146.51 & - \\
\hline 4 & $\mathrm{C}$ & 139.58 & - \\
\hline 5 & $\mathrm{C}$ & 146.51 & - \\
\hline 6 & $\mathrm{CH}$ & 109.33 & $8.40 \mathrm{~s}$ \\
\hline 7 & $\mathrm{CO}$ & 167.09 & - \\
\hline 8 & $\mathrm{OCH}$ & 52.15 & $3.79 \mathrm{~s}$ \\
\hline- & $3 \mathrm{OH}$ & - & $5.39 \mathrm{br}, \mathrm{s}$ \\
\hline
\end{tabular}

Fayoum J. Agric. Res. \& Dev., Vol.19, No.2, July, 2005 
ISOLATION AND IDENTIFICATION OF BACTERICIDE AND..... 62

The fragment ions at $\mathrm{m} / \mathrm{z} 153\left(\mathrm{M}-\mathrm{OCH}_{3}\right)$ and $125\left(\mathrm{M}-\mathrm{COOCH}_{3}\right)$ were further confirmed the presence of these groups $\left(\mathrm{OCH}_{3}\right.$ and $\left.\mathrm{CO}\right)$ and also indicated that the methoxyl group attached to the carbonyl group in the form of ester group. The ${ }^{1} \mathrm{H}-\mathrm{NMR}$ spectrum (Fig.3) showed one methoxyl group ( $\delta 3.79 \mathrm{ppm}, 3 \mathrm{H}$ br.s) and three hydroxyl groups $(\delta 5.39 \mathrm{ppm}, 3 \mathrm{H}$ br.s). The appearance of two aromatic proton signals only at $\delta 6.93(1 \mathrm{H}, \mathrm{s})$ and $\delta 8.4 \mathrm{ppm}$ $(1 \mathrm{H}, \mathrm{s})$ assignable to the protons of $\mathrm{C}-2$ and $\mathrm{C}-6$ respectively in the ${ }^{1} \mathrm{H}-\mathrm{NMR}$ spectrum indicating that the other positions on the phenyl group were substituted. The presence of the three hydroxyl groups on the phenyl group were established by the fragment ion peak at $\mathrm{m} / \mathrm{z} 125\left(\mathrm{M}-\mathrm{COOCH}_{3}\right)$ and the spectral data $\left({ }^{1} \mathrm{H}\right.$ and $\left.{ }^{13} \mathrm{C}-\mathrm{NMR}\right)$.

Thus the structure of this compound was characterized as gallic acid methyl ester (Fig. 4). This methyl gallate which was isolated for the first time from Schinus terebinthifolius is a known compound which was previously isolated from Acacia nilotica (Khalid et al. 1989).

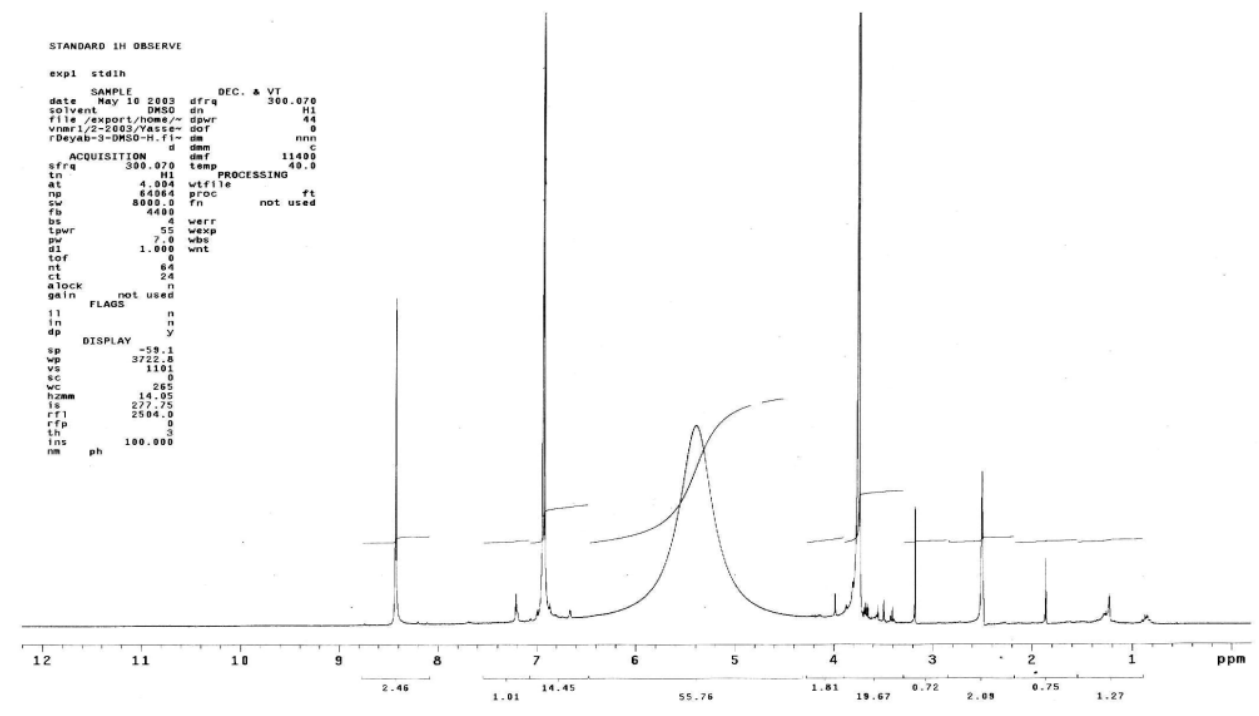

Fig. (3) ${ }^{1} \mathrm{H}-\mathrm{NMR}$ spectrum of the isolated compound in DMSO-d 6<smiles>COc1cc(O)c(O)c(O)c1</smiles>

Fig.(4) Structural formula of the isolated compound $\left(\mathrm{C}_{8} \mathrm{H}_{8} \mathrm{O}_{5}\right)$

The isolated compound (methyl gallate) exerted a miticidal activity against adult females of the two spotted spider mite Tetranychus urticae

Fayoum J. Agric. Res. \& Dev., Vol.19, No.2, July, 2005 
Abdalla M. Moussa, et al.

$\left(\mathrm{LC}_{50}=58 \mathrm{ppm}\right)$ and antibacterial activity against the two pathogenic bacteria Erwinia carotovora and Ralstonia solanacearum (MLC $=250$ and $500 \mu \mathrm{g}$ $/ \mathrm{ml})$ respectively.

REFERENCES

Barakat, A. A.; Shereef, G. M.; Abdallah, S. A. and Amer, S. A. (1984). Effect of some pesticides and plant extracts on some biological aspects of Tetranychus urticae Koch. Bull. Ent.Soc. Egypt, Econ. Ser.14; 225-232

Bauer, A.W.; Kirby, M. M.; Sherris, J. C. and Turck, M. (1966). Antibiotic susceptibility testing by a standardized single disk method. American Journal of Clinical Pathology 45(4):493-496.

Dittrich, V. (1962). A comparative study of toxicological methods on a population of the two spotted spider mite (T. telarius). J.Econ.Ent.55:644-645

Ellen, J; Peterson, L.R and Finegold, S.M.(1994). Diagontive Microbiology. Ninth edition, Part 2, Chap. 14: 168-188. Mosby, Saint Louis, USA

Elphinstone, J.G. (2001). Monitoring and control of the potato brown rot bacterium. European Potato Processing Conference, Lausanne, Switzerland 14-15 November 2001

Farnsworth N.R. (1966). Biological and Phytochemical Screening of Plants. J.Farma .Sci. 55:225-276

Food and Veterinary Office (2000). Report an a Mission carried out in Egypt from 1 to 6 February 2000 to Assess the surveilance system for brown rot in potatoes for export to the EU European Commission, Health and Consumer Protection Directorate general. DG (SANCO) 1056/2000- Mr Final 1-23

Khalid, S. A.; Yagi, S. M.; Khristova, P. and Duddeck, H. (1989). Catechin -5galloyl ester as a novel natural polyphenol from the bark of Acacia nilotica of Sudanese origin. Planta-Medica 55(6): 556-558

Mabry, T. J.; Markham, K. R. and Thomas, M. B. (1970). The systematic identification of flavonoids. Springer Verlag, Berlin, heidlberg, New York

Toth, I. K.; Bell, K. S.; Holeva, B. M. and Birch, P. R. (2003). Soft rot erwiniae from genes to genomes. Molecular Plant Pathology 4(1):17-30

Voss,G.(1961). Einneves Akarizid-Austesungsverfahren fur spinnmilben. Anz.F: Schadlingskde, 34:76-77

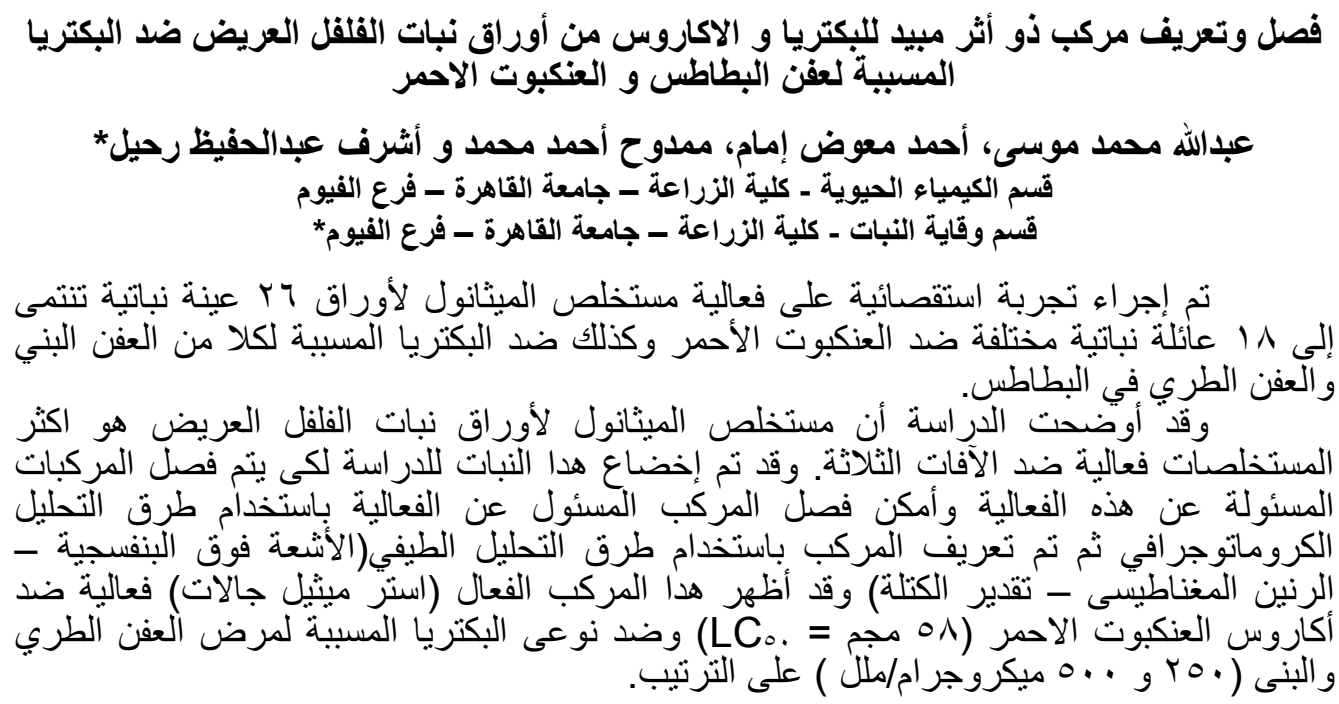

Fayoum J. Agric. Res. \& Dev., Vol.19, No.2, July, 2005 